\title{
Isolation and characterization of a novel streptomyces strain Eri11 exhibiting antioxidant activity from the rhizosphere of Rhizoma Curcumae Longae
}

\author{
Kai Zhong ${ }^{1}$, Xia-Ling Gao ${ }^{1}$, Zheng-Jun $\mathrm{Xu}^{1 *}$, Li-Hua Li ${ }^{1}$, Rong-Jun Chen ${ }^{1}$ \\ Xiao-JianDeng ${ }^{1}$, Hong Gao ${ }^{2}$, Kai Jiang ${ }^{1,3}$ and Isomaro Yamaguchi ${ }^{3}$ \\ ${ }^{1}$ Rice Research Institute, Sichuan Agricultural University, Wenjiang 611130, PR, China. \\ ${ }^{2}$ College of Light Industry, Textile and Food Engineering, Sichuan University, Chengdu 610065, PR, China. \\ ${ }^{3}$ Department of Applied Biological Chemistry, Graduate School of Agricultural and Life Sciences, \\ University of Tokyo, Bunkyo-ku, Tokyo 113-8657, Japan.
}

Accepted 10 May, 2011

In the present study, the phylogenetic analysis of the Streptomyces strain Eri11 isolated from the rhizosphere of Rhizoma Curcumae Longae and the antioxidant activity of the broth cultured with Eri11 were investigated. Analysis of 16S rDNA gene sequences demonstrated that the strains Eri11 was most closely related to representatives of the genera Streptomyces. The total phenols and flavonoids contents in cultured broth were detected to be13.59 $\pm 0.17 \mathrm{mg}$ gallic acid equivalent/g and $9.93 \pm 0.83 \mathrm{mg}$ rutin equivalent $/ \mathrm{g}$, respectively. The cultured broth showed the antioxidant activity against the ABTS (2, 2'-Azinobis-3-ethyl benzthiazoline-6-sulfonic acid) free radicals and hydroxyl free radicals with $\mathrm{IC}_{50}$ (The half-inhibitory concentration) of $223.81 \pm 24.50 \mu \mathrm{g} / \mathrm{ml}$ and $582.42 \pm 83.10 \mu \mathrm{g} / \mathrm{ml}$ respectively. So, it was suggested that the isolated Streptomyces strain Eri11 could be a candidate for the nature resource of the antioxidants.

Key words: Streptomyces, phylogeny, cultured broth, antioxidant activity.

\section{INTRODUCTION}

Actinomycetes play a significant role in the pharmaceutical industry for their capacity to produce secondary metabolites with diverse chemical structures and biological activities. Tens of thousands of such compounds have been isolated and characterized, many of which have been developed into drugs for treatment of wide range of diseases in human, veterinary and agriculture sectors (Castillo et al., 2002; Singh et al., 2003; El-Shatoury et al., 2009). Searching for novel actinomycete that metabolized an essential component in natural product-based drug is becoming more and more interesting and meaningful.

Streptomycetes, the Gram positive filamentous bacteria, belongs to actinomycetales, are widely

\footnotetext{
${ }^{*}$ Corresponding author. E-mail: mywildrice@yahoo.com.cn
} Tel: +86 2882726875 . Fax: +86 2882722661 . distributed in a variety of natural and manmade environments, constituting a significant component of the microbial population in most soils (Hwang et al., 1994; Watve et al., 2001). These bacteria produce about $75 \%$ of commercially and medically useful antibiotics and approximately $60 \%$ of antibiotics, which have been developed for agriculture use (Miyadoh et al., 1993; Takana et al., 1993). Meanwhile, previous studies showed that the Streptomyces could metabolize the compounds with antioxidant activity such as isoflavonoids (Komiyama et al., 1989), diphenazithionin (Hosoya et al., 1996), dihydroherbimycin A (Chang et al., 2007), polysaccharide (He et al., 2008) and protocatechualdehyde (Kim et al., 2008).

Actinomycetes are known to form intimate associations with plants and colonize their internal tissue. Streptomyces spp., Microbispora spp., and Streptosporangium spp., were isolated from roots of different plant species in Italy and from maize in Brazil, 
which showed antagonistic activities against Gram positive bacteria and fungi (Sardi et al., 1992; Araujo et al., 2000). Previous studies showed that a variety of actinomycetes inhabit a wide range of plants as either symbionts or parasites (Sardi et al., 1992; Okazaki et al., 1995; Yuan and Crawford, 1995). They may have important role in plant development and health because they can affect plant growth either by nutrient assimilation or through secondary metabolite productions. The actinomycetes mainly inhabit the soil, and a large number of actinomycetes have already been isolated and described. Recently, the rate of discovery of new actinomycete has decreased, whereas the rate of reisolation of known material has increased. Therefore, many efforts have been made to select and isolate from other biotopes, such as sea water, plant surface and plant tissues.

Rhizoma Curcumae Longae is the one kind of typical Chinese medical plants, which has many pharmacological functions, such as hypolipemic, antitumor, anti-inflammatory, antibacterial, antioxidant, cholagogic, etc (Yang et al., 2010). There are rare reports about isolated streptomyces associated with the rhizosphere of $R$. Curcumae Longae based on literature survey. In the present study, we isolated one streptomyces strain Eri11 from the rhizosphere of $R$. Curcumae Longae in Ya'an city, Sichuan province, Southwest of China, and investigated the phylogeny analysis and antioxidant activity of Eri11 strain.

\section{MATRTIALS AND METHODS}

\section{Chemicals}

2,2'-Azinobis-3-ethyl benzthiazoline-6-sulfonic acid (ABTS), gallic acid, rutin and potassium persulfate were purchased from Sigma-Aldrich (St. Louis, MO). 1,10-Phenanthroline monohydrate, hydrogen peroxide $\left(\mathrm{H}_{2} \mathrm{O}_{2}\right)$, Folin-Ciocalteu reagent, sodium carbonate $\left(\mathrm{Na}_{2} \mathrm{CO}_{3}\right)$, sodium nitrite $\left(\mathrm{NaNO}_{2}\right)$, aluminium trichloride $\left(\mathrm{AlCl}_{3}\right)$, and ferric sulfate $\left(\mathrm{FeSO}_{4}\right)$ were purchased from Zheng Chang Glass and Reagents Co., Ltd., Sichuan.

\section{Isolation of microorganism}

Isolation of Streptomyces associated with rhizosphere of $R$. Curcumae Longae. In the present study, the rhizosphere of the Chinese medicinal plant $R$. Curcumae Longae was collected in Ya'an city of Sichuan province, southwest of China.

S medium (Baker, 1990), ISP-2 medium (Shirling and Gottlieb, 1966), trehalose-proline media (Jiang et al., 2006) and modified Gause II media (Jiang et al., 2006) were chosen for the isolation of actinomycetes. Nalidixic acid $(15 \mu \mathrm{g} / \mathrm{ml}, w / v)$ and potassium dichromate $(25 \mu \mathrm{g} / \mathrm{ml}, \mathrm{w} / \mathrm{v})$ were added to suppress the growth of non-actinobacteria, and then incubated at $28^{\circ} \mathrm{C}$ (Cao et al., 2005).

An amount of $5 \mathrm{~g}$ of rhizosphere of $R$. Curcumae Longae was soaked in the $250 \mathrm{ml}$ flask with $50 \mathrm{ml}$ sterile $6 \%$ peptone broth. The sample was incubated at $28^{\circ} \mathrm{C}, 180 \mathrm{rpm}$ for $30 \mathrm{~min}$, and then $1 \mathrm{ml}$ suspension of sample was diluted with sterile distilled water. An aliquot of $0.1 \mathrm{ml}$ with $10^{-4}$ and $10^{-5}$ dilutions of the suspension were inoculated on the isolation media and incubated at $28^{\circ} \mathrm{C}$ for 14 days, and then checked for microbial growth (Schulz et al., 1993). The colonies were inoculated on $\mathrm{S}$ medium for purification. Stocks were prepared on $\mathrm{S}$ medium and kept at $-70^{\circ} \mathrm{C}$ (under $30 \%$ of glycerol) for long-term storage and at $4^{\circ} \mathrm{C}$ as source culture.

\section{Morphological identification}

Morphological characteristics are the basis for identifying actinobacteria. Isolated strains were identified according to the traditional morphological criteria including characteristics of colonies on the plate, the presence of aerial mycelium, spore mass colour, distinctive reverse colony colour, diffusible pigment, and sporophore and spore chain morphology (Goodfellow and Cross, 1984).

\section{Physiological and biochemical characteristics}

The utilization pattern of carbon sources by the strains was carried out according to the methods of Gottlieb (1961) since it can be used as an aid for species determination (Pridham and Gottlieb, 1948). Tolerance of the strains to $\mathrm{NaCl}$ concentration was also evaluated (Tresner et al., 1968). The actinomycete strain was tested for its ability to produce $\mathrm{H}_{2} \mathrm{~S}$ and melanin pigments (Holding and Collee, 1971).

\section{Phylogenetic analysis (16S rDNA)}

Genomic DNA extraction was done using the procedure described by Xu et al. (2003) and PCR amplification of the 16S rDNA gene was carried out with primers A and B (Xu et al., 2003). The amplified products were sent to Invitrogen Company for purification and sequencing. The quality of the sequences was verified by sequencing both strands. These sequences were submitted to the GenBank database.

Phylogenetic trees were constructed using the Neighbor-Joining method in MEGA program version 4.1 (Kumar et al., 2004). The topology of the phylogenetic tree was evaluated by bootstrap resampling method of Felsenstein with 1000 replicates (Felsenstein, 1985). The 16S rDNA gene sequences of the type strains of the various genera used in this study were retrieved from the nonredundant GenBank database and used for cladistic analysis. These sequences have been chosen as reference sequences, in which unidentified and unpublished sequences were not included.

\section{Extraction of the cultured broth}

The spore suspensions of the culture were inoculated on $S$ liquid media and incubated at $28^{\circ} \mathrm{C}, 180 \mathrm{rpm}$ for 14 days. $\mathrm{S}$ broth with cultures was collected and centrifuged (3000 rpm, $30 \mathrm{~min})$ to remove the streptomyces spore, and the cultured broth without the streptomyces spore was collected to antioxidant test.

\section{Determination of total phenols and flavonoids contents}

Total phenols were determined by using Folin-Ciocalteu method (Velioglu et al., 1998). Analyses were performed by visible spectrophotometry at $750 \mathrm{~nm}$ after reaction with Folin-Ciocalteu's reagent. In brief, an amount of $0.1 \mathrm{ml}$ extract samples with different dilution were mixed with $2 \mathrm{ml}$ of $20 \mathrm{mg} / \mathrm{ml} \mathrm{Na}_{2} \mathrm{CO}_{3}$ for $2 \mathrm{~min}$, and then $0.9 \mathrm{ml}$ of Folin-Ciocalteu's reagent (previously diluted 2-fold with distilled water) was added. The absorbance of reaction was 
Table 1. Cultrual characterization of the streptomyces strain Eri11 cultured on the S solid medium.

\begin{tabular}{llcll}
\hline \multicolumn{2}{l}{ Mycelial colouration } & \multirow{2}{*}{ Melanoid pigmentation } & Spore surface & Spore morphology \\
\hline Aerial & Substrate & & Smooth & Rectiflexibilis \\
\hline Grey & Blue & + & S
\end{tabular}

$+=$ Pigments produced; - = Not produced.

Table 2. Biochemical characteristics of isolated strain Eri11.

\begin{tabular}{|c|c|c|c|c|c|c|}
\hline Catalase & Glucose & Xylose & Arabinose & Rhamnose & Fructose & Galactose \\
\hline+ & + & + & + & - & + & + \\
\hline Raffinose & Mannitol & Inositol & Sucrose & $1.5 \% \mathrm{NaCl}$ & $3 \% \mathrm{NaCl}$ & $5 \% \mathrm{NaCl}$ \\
\hline- & + & + & + & + & + & + \\
\hline
\end{tabular}

measured at $750 \mathrm{~nm}$ by using the MAPADA V-1100D spectrophotometer (Xinke Instruments Co., Ltd., Sichuan, China) after $30 \mathrm{~min}$ of incubation at room temperature. Total phenol contents were calculated as gallic acid from a calibration curve: $Y=$ $1.373 X-0.044, R^{2}=0.997$, where $Y$ was the absorbance and $X$ was the gallic acid equivalent (mg gallic acid/g extract).

Total flavonoids were determined by using spectrophotometrical methods (Ordonez et al., 2006). To $0.1 \mathrm{ml}$ of extract samples with different dilution, $2 \mathrm{ml}$ of distilled water was mixed with $0.1 \mathrm{ml}$ of $5 \%$ $\mathrm{NaNO}_{2}$ for $6 \mathrm{~min}$, and then $0.2 \mathrm{ml}$ of $10 \% \mathrm{AlCl}_{3}$ were added and mixed for $5 \mathrm{~min}$. The total volume was made up to $3 \mathrm{ml}$ with distilled water. The absorbance of reaction was measured at $420 \mathrm{~nm}$ against a prepared blank by using the MAPADA V-1100D spectrophotometer. Total flavonoids contents were calculated as rutin from a calibration curve: $Y=0.525 X, R^{2}=0.999$, where $X$ was the absorbance and $Y$ was the rutin equivalent (mg rutin/g extract).

\section{ABTS radical scavenging activity}

ABTS radical scavenging activity was determined according to a modified method (Re et al., 1999). In brief, $19 \mathrm{mg}$ of ABTS was reacted with $3.3 \mathrm{mg}$ of potassium persulfate overnight in the dark at room temperature. The working solution was prepared by diluting it with water to get absorbance around 0.70 at $734 \mathrm{~nm}$. An amount of $30 \mu \mathrm{l}$ of test sample was reacted with $2.97 \mathrm{ml}$ of diluted ABTS and absorbance was recorded within $30 \mathrm{~min}$ at $734 \mathrm{~nm}$. Trolox was used as a positive. The activity was expressed as the concentration of sample necessary to give a $50 \%$ reduction in the original absorbance $\left(\mathrm{IC}_{50}\right)$.

\section{Hydroxyl radical $(\cdot \mathrm{OH})$ scavenging activity}

Hydroxyl radical scavenging activity was determined according to a modified method ( $\mathrm{Li}$ et al., 2010). To $1.0 \mathrm{ml}$ of $0.75 \mathrm{mM} \mathrm{1,10-}$ phenanthroline monohydrate, $2 \mathrm{ml}$ of $\mathrm{pH} 7.4$ PBS buffer were mixed with $1 \mathrm{ml}$ distilled water and $1 \mathrm{ml}$ of $0.75 \mathrm{mM} \mathrm{FeSO}_{4}$ was then added. An amount of $1 \mathrm{ml}$ of $0.01 \% \mathrm{H}_{2} \mathrm{O}_{2}$ was added after mixed. The absorbance of reaction was measured at $536 \mathrm{~nm}$ after $1 \mathrm{~h}$ of incubation at $37^{\circ} \mathrm{C}$. The percentage (\%) of radical scavenging activity (RSA) was calculated using the following equation:

$\operatorname{RSA}(\%)=\left[\left(A_{S}-A_{P}\right) /\left(A_{B}-A_{P}\right)\right] \times 100$ where $A_{S}$ is the absorbance of the sample at $536 \mathrm{~nm}$, and $A_{P}$ is the absorbance of the positive control which $1 \mathrm{ml}$ distilled water instead of $1 \mathrm{ml}$ sample in the reaction system at $536 \mathrm{~nm}$, and $A_{B}$ is the absorbance of the control which $1 \mathrm{ml}$ distilled water was added to the reaction system instead of $1 \mathrm{ml}$ of $0.01 \% \mathrm{H}_{2} \mathrm{O}_{2}$ at $536 \mathrm{~nm}$.

\section{Statistical analysis}

The data of all experiments were recorded as means \pm standard deviations and were analyzed with SPSS (version 17.0 for Windows, SPSS Inc.). Differences were considered significant at $\mathrm{P}$ $<0.05$.

\section{RESULTS AND DISCUSSION}

In the present study, the Streptomyces strain Eri11 was isolated from the rhizosphere of $R$. Curcumae Longae, one of the Chinese medical plants. The morphology of the strain Eri11 sporophore after cultured on S medium for 7 days showed rectiflexibilis pattern. The colonies were aerobic and grew slowly. The colour pattern of the strain Eri11 mycelia grown on $S$ medium was totally shown in Table 1. The colour of arial mycelia was grey, and the colour of substrate mycelia was blue. The strain Eri11 was Gram-positive according to the result of the Gram's staining. The strain produced melanoid pigments (Table 1). A great variety of biochemical features of the strain Eri11 were also studied. As shown in Table 2, the strain Eri11 could utilize the carbon sources efficiently including glucose, xylose, arabinose, fructose, galactose, mannitol, inositol and sucrose. Tolerance of the strains to $\mathrm{NaCl}$ concentration also served as an important character for species identification. The maximum tolerance of the strain Eri11 to $\mathrm{NaCl}$ was $5 \%$.

In order to classify the isolated strain based on its biochemical traits, the phylogeny analysis of the strain Eri11 was investigated. Phylogeny of the strain based on 


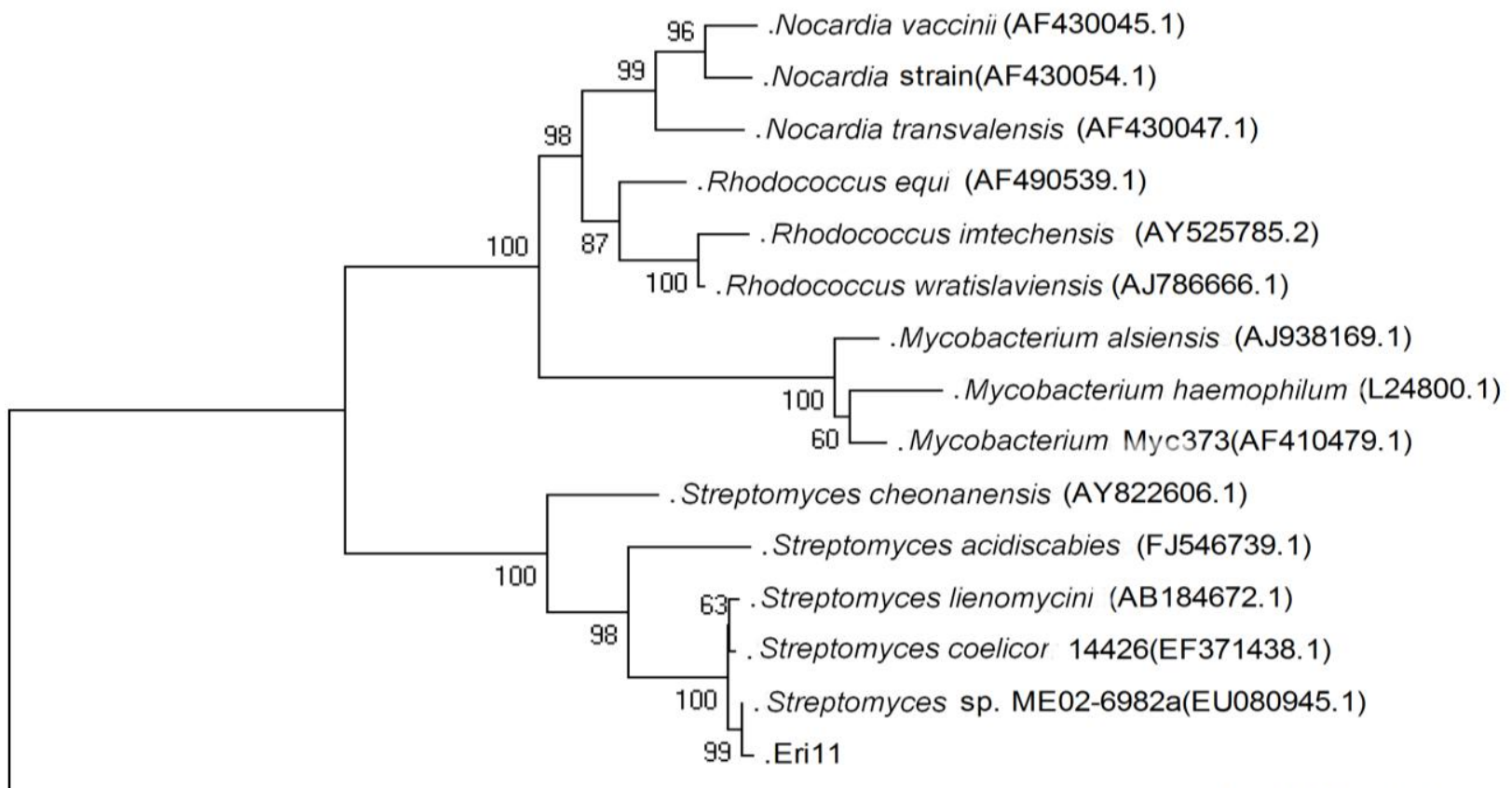

Bacillus subtilis subsp(AB271744.1)

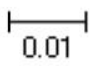

Figure 1. Phylogenetic tree based on the $16 \mathrm{~S}$ rDNA sequences of the showing affiliation of Eri11 strain with closely related members in GenBank. Bacillus subtilis (AB271744.1) was used as an outgroup. Phylogenetic trees were generated using MEGA version 4.1 with default parameters, K2P distance model and the Neighbor-Joining algorithm. The numbers at the branching prints are the percentages of occurrence in 1000 bootstrapped tree.

Table 3. Total phenols and flavonoids in the cultured broth extract and its antioxidant activity.

\begin{tabular}{ll}
\hline Total phenols contents & $13.59 \pm 0.17 \mathrm{mg}$ gallic acid equivalent/g cultured broth \\
Total flavonoids contents & $9.93 \pm 0.83 \mathrm{mg}$ rutin equivalent $/ \mathrm{g}$ cultured broth \\
ABTS radical scavenging activity & $\mathrm{IC}_{50}=223.81 \pm 24.50 \mu \mathrm{g} / \mathrm{ml}$ \\
Hydroxyl radical scavenging activity & $\mathrm{IC}_{50}=582.42 \pm 83.10 \mu \mathrm{g} / \mathrm{ml}$ \\
\hline
\end{tabular}

the sequencing of the $16 \mathrm{~S}$ rDNA, had become the method of choice for tracing bacterial phylogenies and defining taxonomy (Yin et al., 2008). To elucidate the taxonomic positions of the isolated strain, we sequenced the full length of 16S rDNA gene of the strain Eri11. A continuous stretch of $1561 \mathrm{bp}$ (including gaps) was used for building the phylogenetic Neighbor-Joining tree by using MEGA version 4.1 with default parameters, K2P distance model and the Neighbor-Joining algorithm. The confidence of the grouping was verified by bootstrap analysis (1000 replications). Bacillus subtilis (AB271744.1) was used as an outgroup. From the phylogenetic tree (Figure 1), the actinomycete isolated from $R$. Curcumae Longae was classified into Streptomyces. The 16S rDNA gene sequence of Eri11 showed high similarity of $99.4 \%$ to that of Streptomyces coelicor 14426 (EF371438.1). Phylogenetic tree revealed that Eri11 is strongly related to Streptomyces forming a distinct cluster (Figure 1).

Cultured with the isolated strain Eri11 in the S medium broth for 14 days, there were some kinds of antioxidants produced. It has been reported that many flavonoids and flavonols exhibited prominent antioxidant behavior as a result of their ability to scavenge radicals (Torres et al., 2002). Therefore, we investigated the total contents of phenols and flavonoids of cultured broth by using the Folin-Ciocalteu method and $\mathrm{AlCl}_{3}$ colormetric method, respectively. By using the Folin-Ciocalteu method, the total phenols contents in the cultured broth were calculated to be $13.59 \pm 0.17 \mathrm{mg}$ gallic acid equivalent $/ \mathrm{g}$ cultured broth (Table 3). Meanwhile, by using $\mathrm{AlCl}_{3}$ colormetric method, the total flavonoids contents in the 


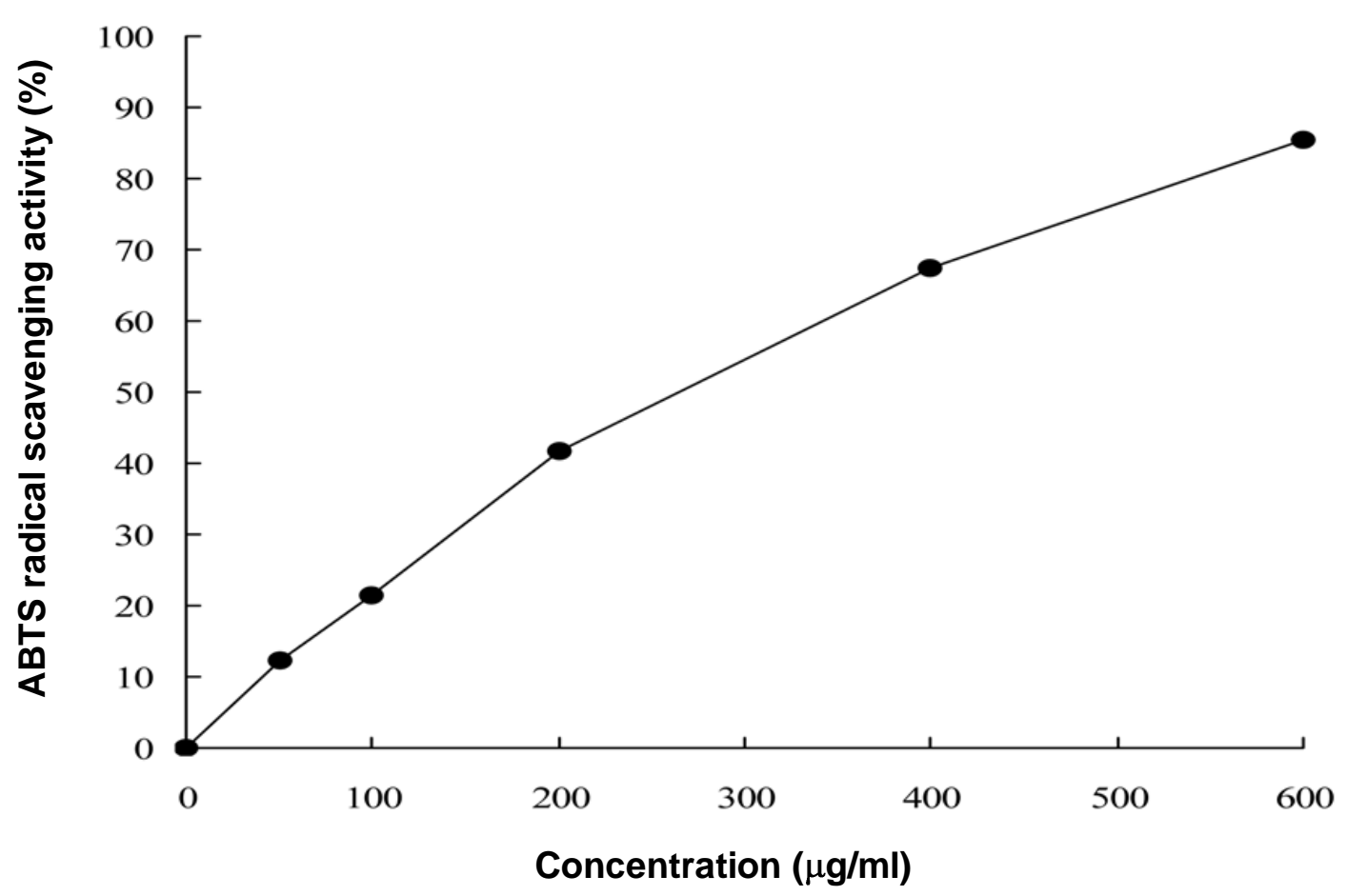

Figure 2. ABTS radical scavenging activity of the cultured broth extract from Streptomyces strain Eri11.

cultured broth were calculated to be $9.93 \pm 0.83 \mathrm{mg}$ rutin equivalent/g cultured broth.

The ABTS radical cation decolorization assay is one of methods for the screening of the antioxidant activity (Re et al., 1999). The pre-formed radical monocation of 2,2'azinobis-(3-ethylbenzothiazoline-6-sulfonic acid) $\left(\right.$ ABTS $^{\circ+}$ ) is generated by oxidation of ABTS with potassium persulfate and is reduced in the presence of such hydrogen-donating antioxidants. Therefore, the ABTS radical scavenging activity of the cultured broth was determined.

After reacting for $30 \mathrm{~min}$, the cultured broth showed ABTS radical scavenging activities of $12.41 \%$ at 50 $\mu \mathrm{g} / \mathrm{ml}, 21.42 \%$ at $100 \mu \mathrm{g} / \mathrm{ml}, 41.61 \%$ at $200 \mu \mathrm{g} / \mathrm{ml}$, $67.53 \%$ at $400 \mu \mathrm{g} / \mathrm{ml}$, and $85.54 \%$ at $600 \mu \mathrm{g} / \mathrm{ml}$, respectively. The results indicated that the cultured broth showed a lesser tendency to decay ABTS radicals at low concentrations of reaction than at high concentrations. As shown in Figure 2, the cultured broth scavenged ABTS radicals in a concentration-dependent manner. The halfinhibitory concentration $\left(\mathrm{IC}_{50}\right)$ was estimated at $223.81 \pm$ $24.50 \mu \mathrm{g} / \mathrm{ml}$ with a linear regression. The antioxidant activity of the cultured broth was about 300 times lower than that of the positive control (Trolox, $I_{50}=0.76 \mu \mathrm{g} / \mathrm{ml}$ ) (Table 3). This different half-inhibitory concentration between the cultured broth and the standard antioxidant can be explained in terms of the fact that the active components in the cultured broth comprise only a fraction of the cultured broth. When considered total phenols or flavonoids contents, the cultured broth showed ABTS radical scavenging activity with $\mathrm{IC}_{50}$ values of $3.04 \mu \mathrm{g} / \mathrm{ml}$ (calibrated with total phenols presented in the cultured broth) and $2.22 \mu \mathrm{g} / \mathrm{ml}$ (calibrated with total flavonoids presented in the cultured broth), respectively.

To determine the antioxidant activity of the cultured broth, hydroxyl radicals scavenging activity test, another typical method, was adopted. Phenanthroline monohydrate- $\mathrm{Fe}^{2+}$ is a common indicator of redox reaction. The change of Phenanthroline monohydrate$\mathrm{Fe}^{2+}$ color could indicate the redox reaction of the reagent. Hydroxyl radical is one kind of strong oxidizers, which could be produced after the chemical reaction between hydrogen peroxide and $\mathrm{Fe}^{2+}$. The content of hydroxyl radical of the reaction system is determined by the change of the indicator (Phenanthroline monohydrate- $\mathrm{Fe}^{2+}$ ) color. Therefore, the hydroxyl radical scavenging activity of the cultured broth was determined according to the change of the indicator (Phenanthroline monohydrate- $\mathrm{Fe}^{2+}$ ) colour.

After reacting for $1 \mathrm{~h}$, the cultured broth showed hydroxyl radical scavenging activities of $0.11 \%$ at 200 $\mu \mathrm{g} / \mathrm{ml}, 19.71 \%$ at $400 \mu \mathrm{g} / \mathrm{ml}, 51.80 \%$ at $600 \mu \mathrm{g} / \mathrm{ml}$, $72.30 \%$ at $800 \mu \mathrm{g} / \mathrm{ml}$, and $96.28 \%$ at $1000 \mu \mathrm{g} / \mathrm{ml}$, respectively. The results indicated that the cultured broth at low concentrations showed a lesser tendency to decay hydroxyl radicals than at high concentrations. As shown in Figure 3, the cultured broth scavenged hydroxyl radicals in a concentration-dependent manner. The halfinhibitory concentration $\left(\mathrm{IC}_{50}\right)$ was estimated at $582.42 \pm$ $83.10 \mu \mathrm{g} / \mathrm{ml}$ with a logarithmic regression. The 


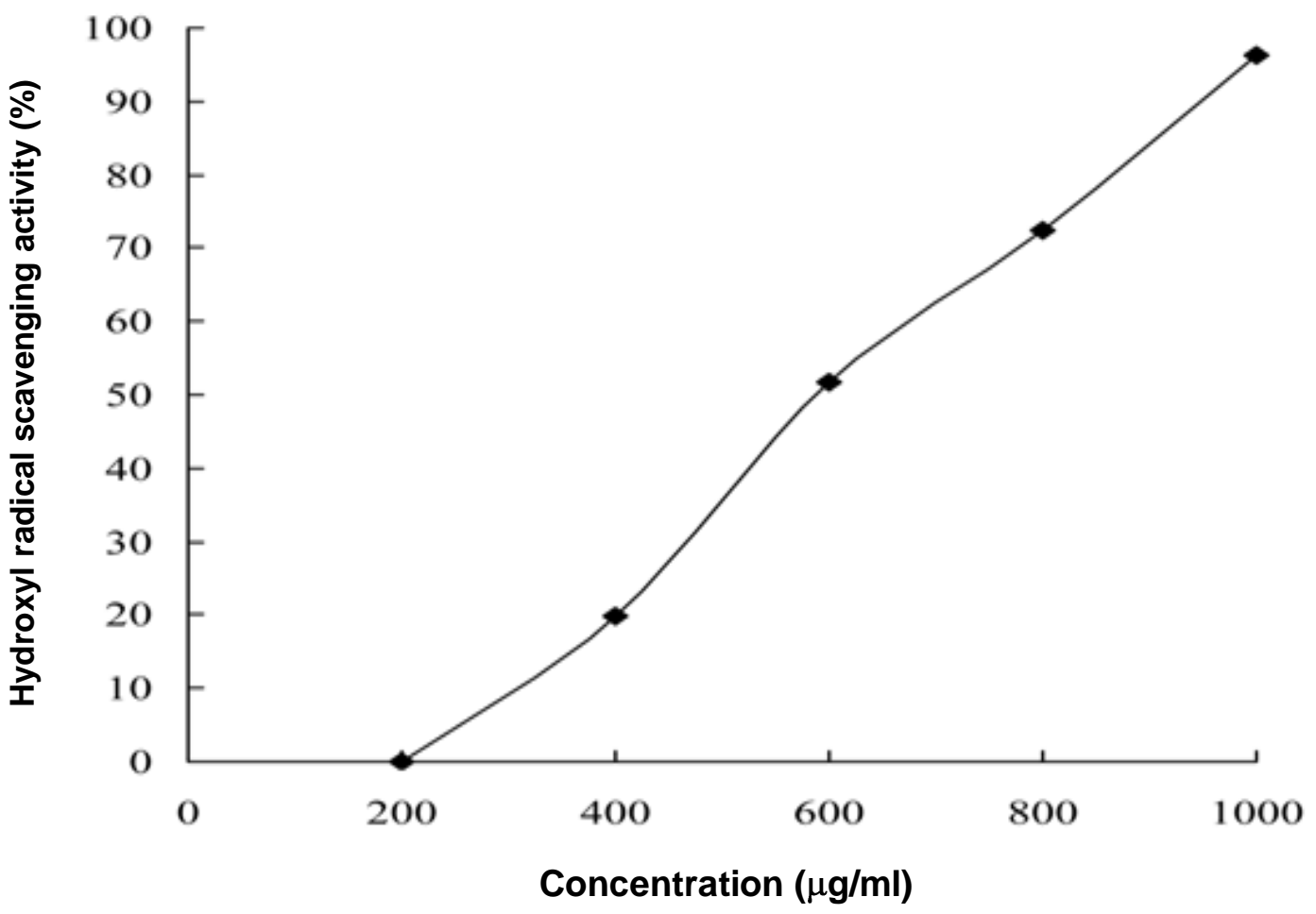

Figure 3. Hydroxyl radical scavenging activity of the cultured broth extract from Streptomyces strain Eri11.

antioxidant activity of the cultured broth was about 400 times lower than that of the positive control (Vitamin C, $\left.I_{50}=1.37 \mu \mathrm{g} / \mathrm{ml}\right)($ Table 3$)$. This different half-inhibitory concentration between the cultured broth and the standard antioxidant can be explained in terms of the fact that the active components in the cultured broth comprise only a fraction of the cultured broth. When considered total phenols or flavonoids contents, the cultured broth showed hydroxyl radical scavenging activity with $\mathrm{IC}_{50}$ values of $7.92 \mathrm{\mu g} / \mathrm{ml}$ (calibrated with total phenols presented in the cultured broth) and $5.78 \mu \mathrm{g} / \mathrm{ml}$ (calibrated with total flavonoids presented in the cultured broth), respectively.

\section{Conclusion}

The present study indicated that the strain Eri11 isolated from the rhizosphere of $R$. Curcumae Longae was a novel streptomyces strain based on the morphological characteristics, biochemical traits and phylogeny analysis. According to the results of the antioxidant activity tests, it suggested that the strain Eri11 could metabolize antioxidants in $\mathrm{S}$ liquid medium. Thus, it will prove to be a good candidate as the antioxidant products for industry. Further work is in progress in our laboratory to elucidate the identity of compounds responsible for the antioxidant activity.

\section{REFERENCES}

Araujo JM, Silva AC, Azevedo JL (2000). Isolation of endophytic actinomycetes from roots and leaves of maize (Zeamays L.). Braz. Arch. Biol. Techn., 43: 447-451.

Baker D (1990). Methods for the isolation, culture and characterization of the Frankiaceae: soil actinomycetes and symbionts of actinorhizal plants. In: Labeda D.P., Ed., Isolation of Biotechnological Organisms from Nature, McGraw-Hill Publishing Co, New York, pp. 213-236.

Cao LX, Quu ZQ, You JL, Tan HM, Zhou SN (2005). Isolation and characterization of endophytic streptomycete antagonists of fusarium wilt pathogen from surface-sterilized banana roots. FEMS Microbiol. Lett., 247: 147-152.

Castillo UF, Strobel GA, Ford EJ, Hess WM, Porter H, Jensen JB, Albert H, Robison R, Condron MAM, Teplow DB (2002). Munumbicins, wide-spectrum antibiotics produced by Streptomyces NRRL 30562, endophytic on Kennedia nigriscans. Microbiology, 148: 2675-2685.

Chang HB, Kim J (2007). Antioxidant properties of dihydroherbimycin A from a newly isolated Streptomyces sp. Biotechnol. Lett., 29: 599-603.

El-Shatoury SA, El-Shenawy NS, Abd El-Salam IM (2009). Antimicrobial, antitumor and in vivo cytotoxicity of actinomycetes inhabiting marine shellfish. World J. Microbiol. Biotech., 25: 1547-1555.

Felsenstein $J$ (1985). Conference limits on phylogenies: an approach using the bootstrap. Evolution, 39: 783-789.

Goodfellow M, Cross T (1984). Classification. In: Goodfellow M., Mordarski M., Eds, The Biology of the Actinomycetes, Academic Press, London, pp. 7-164.

Gottlieb D (1961). An evolution of criteria and procedures used in the description and characterization of Streptomyces, A cooperative study. Appl. Microbiol., 9: 55-60. 
He F, Yang Y, Yang G, Yu L (2008). Components and Antioxidant Activity of the Polysaccharide from Streptomyces virginia H03. Zeitschrift fur Naturforschung C-J. Biosci., 63: 181-188.

Holding AJ, Collee JG (1971). Routine Biochemical tests. Methods Microbiol., 6A: 1-31.

Hosoya $\mathrm{Y}$, Adachi $\mathrm{H}$, Nakamura $\mathrm{H}$, Nishimura $\mathrm{Y}$, Naganawa $\mathrm{H}$, Okami Y, Takeuchi T (1996). The structure of diphenazithionin, a novel antioxidant fromStreptomyces griseus ISP 5236. Tetrahedron Lett., 37: 9227-9228.

Hwang BK, Ahn SJ, Moon SS (1994). Production, purification and antifungal activity of the antibiotic nucleoside, tuberecidine, produced by Streptomyces violaceonig. Can. J. Bot., 72: 480485.

Jiang Y, Duan SR, Tang SK, Chen HX, Li WJ, Xu LH (2006). The isolation method of rare actinomycetes. Microbiology (Chinese), 33: 181-183.

Kim KJ, Kim MA, Jung JH (2008). Antitumor and antioxidant activity of protocatechualdehyde produced from Streptomyces lincolnensis M-20. Arch. Pharmacal. Res., 31: 1572-1577.

Komiyama K, Funayama S, Anraku Y, Mita A, Takahashi Y, Omura $\mathrm{S}$, Shimasaki $\mathrm{H}$ (1989). Isolation of isoflavonoids possessing antioxidant activity from the fermentation broth of Streptomyces sp. J. Antibiotics., 42: 1344-1349.

Kumar S, Tamura K, Nei M (2004). MEGA3: integrated software for molecular evolutionary genetics analysis and sequence alignment. Brief. Bioinform., 5: 150-163.

Li XP, Liang Q, Xin XL, Wang YH (2010). Study on the antioxidation activity of extraction of ellagic acid from red raspberry. (Chinese), Food Sci. Technol., 35(5): 182-185.

Miyadoh S (1993). Research on antibiotic screening in Japan over the last decade: A producing microorganisms approach. Actinomycetologica, 9: 100-106.

Okazaki T, Takahashi K, Kizuka M, Enokita R (1995). Studies on Actinomycetes isolated from plant leaves. Annu. Rep. Sankyo Res. Lab., 47: 97-106.

Ordonez AAL, Gomez JD, Vattuone MA, Isla MI (2006). Antioxidant activities of Sechium edule (Jacq.) Swartz extracts. Food Chem., 99: 452-458.

Pridham TG, Gottlieb D (1948). The utilization of carbon compounds by some actinomycetales as an aid for species determination. J. Bacteriol., 56: 107-114.

Re R, Pellegrini N, Proteggente A, Panala A, Yang M, Rice-Evans C (1999). Antioxidant Activity Applying an Improved ABTS Radical Cation Decolorization Assay. Free Radic. Biol. Med., 26: 1231-1237.
Sardi P, Saracchi M, Ouaroni S, Petrolini B, Borgonovoli GE, Merli S (1992). Isolation of endophytic Streptomyces from surfacesterilized roots. Appl. Environ. Microbiol., 58: 2691-2693.

Schulz B, Wanke U, Draeger S, Aust HJ (1993). Endophytes from herbaceous plants and shrubs: effectiveness of surface sterilization methods. Mycol. Res., 97: 1447-1450.

Shirling EB, Gottlieb D (1966). Methods for characterization of Streptomyces species. Int. J. Syst. Bacteriol., 16: 313-340.

Singh MP, Petersen PJ, Weiss WJ, Janso JE, Luckman SW, Lenoy EB, Bradford PA, Testa RT, Greenstein M (2003). Mannopeptimycins, new cyclic glycopeptide antibiotics produced by Streptomyces hygroscopicus LL-AC98: antibacterial and mechanistic activities. Antimicrob. Agents Chemother., 47: 62-69.

Tanaka YT, Mura SO (1993). Agroactive compounds of microbial origin. Ann. Rev. Microbiol., 47: 57-87.

Torres JL, Varela B, García MT, Carilla J, Matito C, Centelles JJ, Cascante M, Sort X, Bobet R (2002). Valorization of grape (Vitis vinifera) by-products. Antioxidant and biological properties of polyphenolic fractions differing in procyanidin composition and flavonol content. J. Agric. Food Chem., 50: 7548-7555.

Tresner HD, Hayes JA, Backns EJ (1968). Differential tolerance of Streptomyces to sodium chloride as a taxonomic aid. Appl. Microbiol., 16: 1134-1136.

Velioglu YS, Mazza G, Gao L, Oomah BD (1998). Antioxidant activity and total phenolics in selected fruits, vegetables, and grain products. J. Agric. Food Chem., 46: 4113-4117.

Watve MG, Tichoo R, Jog MM, Bhole BD (2001). How many antibiotics are produced by the genus Streptomyces. Arch. Microbiol., 176: 386-390.

Xu P, Li WJ, Xu LH, Jiang CL (2003). A microwave-based method for genomic DNA extraction from Actinomycetes. Microbiology (Chinese)., 30(4): 73-75.

Yang YF, MSc MD (2010). Chinese Herbal Medicines (Second Edition), pp. 229-254.

Yin H, Cao L, Xie M, Chen Q, Qiu G, Zhou J, Wu L, Wang D, Liu X (2008). Bacterial diversity based on 16S rDNA and gyrB genes at Yinshan mine, China. Syst. Appl. Microbiol., 31: 302-311.

Yuan WM, Crawford DL (1995). Characterization of Streptomyces lydicus WYEC108 as a potential biocontrol agent against fungal root and seed rots. Appl. Environ. Microbiol., 61: 3119-3128. 